\title{
The Effect of Sport Activity on the Elderly Health- Related Physical Fitness
}

\author{
Nurlan Kusmaedi* \\ Department of Health and Recreation Education \\ Universitas Pendidikan Indonesia \\ Bandung, Indonesia \\ *nurlankusmaedi@upi.edu
}

\begin{abstract}
The purpose of the present study was to measure health related physical fitness status of the elderly who were active in five kinds of sport; and to describe the difference of training effect of five kinds of sport on the elderly health related physical fitness status. The expost facto method was used for this study. Subjects who participated in the study were seventy-four elderlies, and their five respective sport health clubs situated in Bandung, including lawn tennis (12), walking (16), table tennis (13), gymnastic (15), and badminton (15). The instrument used was physical fitness test proposed by "the Centre for Study and Development of Sports Science and Technology Office of the State Minister for Youth and Sports", consisting of general endurance $(2,4 \mathrm{~km}$ walks), muscular endurance (push up and sit up), flexibility (sit and reach test), and strength (arms curl). SPSS 2014 was used for data analysis. The result of this study were: 1 . The rank of general endurance status according to gain score was: badminton, lawn tennis, table tennis, gymnastics, walking; 2. The rank of Muscular endurance: lawn tennis, walking, gymnastics, table tennis, badminton; 3. The rank of strength: lawn tennis, walking, badminton, gymnastics, table tennis; 4 . The rank of flexibility: gymnastics, tennis, badminton, table tennis, walking; 5. The rank of Body mass index: walking, gymnastics, badminton, table tennis, lawn tennis. Conclusions: The activities of five kinds of sport could give a good effect as an effort to increase the significant health related physical fitness, including the general endurance, muscular endurance, flexibility, strength, and body mass index; The activities of five kinds of sport give significant differences to increase health related physical fitness aspects.
\end{abstract}

\section{Keywords: sport activity, health related physical fitness}

\section{INTRODUCTION}

This study can be classified into types of recreational sports, the main products are health and fitness [1]. Physical fitness according to the Centre for Study and Development of Sports Science and Technology Office of the State Minister for Youth and Sports is written by the editorial team of Iskandar, is the ability to perform daily activities with full vitality and alertness without experiencing significant fatigue and still enough energy to relax at leisure and face things that are an emergency [2]. There are two aspects of physical fitness, namely: physical fitness related to health (health related physical fitness), include: cardiorespiratory (general) endurance, muscular strength, muscular endurance, flexibility, body composition; and physical fitness-related skills (skill related physical fitness), include: coordination, balance, reaction time, speed, agility, accuracy, and explosive power. The components of physical fitness related to health needed to restore, maintain, or improve health, overcoming environmental stress, and perform daily activities. Components of physical fitness-related skills, need for independence [3,4].

Physical fitness of a person definitely dropped with age, Fitness level declines with age but probably not at the uniform rate, and a significant decrease in physical fitness occurs with advancing age, especially in those abilities that are related to mobility and risk for falls. The age of $70-80$ years seems to be a critical period of life [5] and FF 10-15\% per decade in individuals aged 60-94 years [6-8].

Physical fitness related to health can be obtained by means of physical activity programmed according to ability and age. Physical activity that can be used is to do sports activities tennis, walking, table tennis, aerobics, badminton. Each sport has specific characteristics or abilities dominant components of fitness required to do so. Jan Lexell, "Elderly men and women can improve their aerobic fitness and endurance as well as balance, strength and flexibility up to a very advanced age [9].

Many of elderly people do not understand, that sport activities where is managing well can become a physical activity to increase recorded/measured physical fitness. There are many sport activities, but it is important to choose one of sport activities which is adapt to elderly ability and age. It is better for elderly to do sport activities which have done for a long time before, so that it is very easy to implementation. Besides that, the elderly health related physical fitness level not from the beginning.

To know in what level or status is the elderly physical fitness related to health, it is needed to measure or to test with valid instrument.

\section{A. Problems Proposed Study}

Some problems proposed in the study are:

- Are there the difference effect of sport activities id est lawn tennis, walking, table tennis, gymnastic, badminton to elderly physical fitness related to health?

- Are there the difference effect of sport activities id est lawn tennis, walking, table tennis, gymnastic, 


\begin{tabular}{|lll|}
\hline T1(X1-lawn tennis) & O & (Y-hrpf: Y1, Y2, Y3, Y4) \\
T2 (X2-walking) & O & (Y-hrpf: Y1, Y2, Y3, Y4) \\
T3(X3-table tennis) & O & (Y-hrpf: Y1, Y2, Y3, Y4) \\
T4 (X4-gymnastic) & O & (Y-hrpf: Y1, Y2, Y3, Y4) \\
T5 (X5-badminton) & O & (Y-hrpf: Y1, Y2, Y3, Y4) \\
\hline
\end{tabular}

Fig. 1. Five parallel static group post test design.

\section{RESULTS}

of lawn tennis, walking, table tennis, gymnastics, badminton on the status of health-related physical fitness, of the elderly;

- To reveal the differences in the effect of sport activities of lawn tennis, walking, table tennis, gymnastics, badminton against the order of the dominant components of health-related physical fitness, of the elderly id est general endurance, muscle endurance, flexibility and strength.

\section{Hypothesis Study}

Hypothesis of this study are there are significant differences in the effect of exercise activity of tennis courts, walking, table tennis, gymnastics, badminton against: (1) health-related physical fitness, (2) the dominant components of health-related physical fitness, of the elderly id est general endurance, muscle endurance, flexibility and strength.

\section{METHOD}

The method used is' expose facto 'by design' the five parallel static group post-test design ". The sample was 74 people a member of five elderly sports clubs, with details of 12 tennis courts, walking 16, table tennis 13, gymnastics 15, badminton 15 . Independent variables are denoted by the letter $\mathrm{X}$ in this study is a sports activity tennis courts (X1), walking (X2), table tennis (X3), gymnastics (X4), badminton (X5). Dependent variable is denoted by the letter $\mathrm{Y}$, namely physical fitness related to health (Y). Variables of $\mathrm{Y}$ consists of four sub-variables, namely general endurance (Y1), muscle endurance (Y2), flexibility (Y3) and strength (Y4).

Of the two methods of measurement of physical fitness related to health as stated by Mood DP, that "Physical fitness can be directly Measured with either laboratory or field methods" [10], this study uses "field methods" the instrument used to measure the health related physical fitness refers to the physical fitness test proposed by the Centre for Study and Development of Sports Science and Technology Office of the Minister of Youth and Sports. The difference in the effect of the activity of each sport activity against Health-Related Physical Fitness (HRPF), using one-way anova with SPSS 18 for windows.

Health Related Physical Fitness test are: general endurance using the 12-minute test, muscular endurance using push ups and sit ups tests, muscle strength was measured right hand grip strength and left-hand grip strength, the flexibility use sit and reach test, measurement of body mass index.

The design used in this study is expost facto "the five parallel static group post-test design" as shown in Figure 1:

\section{A. Hypothesis Testing}

Statistical analysis techniques were used to test the first and second hypothesis is the one-way ANOVA using the computer program SPSS 18 for window. Before testing the hypothesis, one-way ANOVA is used, there are some prerequisite testing called statistical hypotheses testing. Prerequisite test includes tests of normality and homogeneity tests. If the data were normally distributed and homogeneous, the hypothesis testing can be continued by using statistical parametric one-way ANOVA.

1) Test for normality. The following SPSS output table test results with the technique Kolmogorov Smirnov normality:

TABLE I. RESUlTS OF NORMALITY TEST

\begin{tabular}{|c|c|c|c|c|c|c|}
\hline & \multirow{2}{*}{ Sport } & \multicolumn{3}{|c|}{ Kolmogorov-Smirnova } & \multirow{2}{*}{$\alpha=0,05$} & \multirow{2}{*}{ Conclusion } \\
\hline & & Statistic & $d f$ & Sig. & & \\
\hline \multirow{5}{*}{ HRPF } & Lawn tennis & ,099 & 12 &, $200 *$ & 0,05 & Normal \\
\hline & Walking &, 155 & 16 & ,200* & 0,05 & Normal \\
\hline & Table tennis & 166 & 16 & $200 *$ & 0,05 & Normal \\
\hline & Gymnastic &, 153 & 15 &, $200 *$ & 0,05 & Normal \\
\hline & Badminton &, 126 & 15 & $200 *$ & 0,05 & Normal \\
\hline
\end{tabular}

From the normality test results above we know that the data is normal.

2) Homogenity test. The following SPSS output tables homogeneity test results:

TABLE II. Homogenity Test CALCUlation Results

\begin{tabular}{|l|l|l|l|l|l|l|l|}
\hline \multicolumn{2}{|c|}{} & $\begin{array}{c}\text { Levene } \\
\text { Statistic }\end{array}$ & $\begin{array}{c}\text { df } \\
\mathbf{1}\end{array}$ & $\mathbf{d f 2}$ & Sig. & $\begin{array}{c}\alpha= \\
\mathbf{0 , 0 5}\end{array}$ & Conclusion \\
\hline \multirow{5}{*}{ HRPF } & Based on Mean & 954 & 4 & 69 &, 438 & 0,05 & Homogen \\
\cline { 2 - 6 } & $\begin{array}{l}\text { Based on Median } \\
\text { Based on Median } \\
\text { and with adjusted df }\end{array}$ &, 907 & 4 & 69 &, 465 & & \\
\cline { 2 - 5 } & $\begin{array}{l}\text { Based on trimmed } \\
\text { mean }\end{array}$ & 4 & $\begin{array}{l}56,9 \\
9\end{array}$ &, 466 & & \\
\hline
\end{tabular}

From the test results above we know that the data is homogeneous.

Because the data were normally distributed and homogeneous the data, then the data ineligible for parametric statistical test that is One Way Anova. 
- Ho is accepted if the value of sig. $>0.05$

\section{3) Hypothesis testing}

a) First hypothesis: There are significant differences in the effect of exercise activity of lawn tennis, walking, table tennis, gymnastics, badminton against health-related physical fitness.

Criteria:

- Ho is accepted if the value of sig. $>0.05$

- Ho is rejected if the value of sig. $<0.05$

The results are as follows:

TABLE III. RESULTS OF ONE WAY ANOVA (HRPF)

\begin{tabular}{|l|l|c|l|l|l|}
\hline & Sum of Squares & $\begin{array}{l}\text { d } \\
\text { f }\end{array}$ & Mean Square & F & $\begin{array}{l}\text { Si } \\
\text { g. }\end{array}$ \\
\hline $\begin{array}{l}\text { Between } \\
\text { Groups }\end{array}$ & 55645,033 & 4 & 13911,258 & $\begin{array}{l}14,85 \\
5\end{array}$ & $\begin{array}{l}, 00 \\
0\end{array}$ \\
\hline Within & 64615,642 & 6 & 936,459 & & \\
Groups & & 9 & & & \\
\hline Total & 120260,675 & 7 & & & \\
\hline
\end{tabular}

Based on the table above, note that the value of sig. 0.000 $<0.05$ thus Ho is rejected. So there are differences in mean Health Related Physical Fitness among groups that practice sports activities lawn tennis, walking, table tennis, gymnastics, and badminton.

b) Second hypothesis testing: There are significant differences in the effect of exercise activity of lawn tennis, walking, table tennis, gymnastics, badminton against components of health related physical fitness id est general endurance, muscle endurance, flexibility and strength.

Criteria:
- Ho is rejected if the value of sig. $<0.05$

The results are as follows:

TABLE IV. RESULTS OF ONE WAY ANOVA (SRPF)

\begin{tabular}{|l|l|l|l|l|l|}
\hline & \multicolumn{1}{|c|}{$\begin{array}{c}\text { Sum of } \\
\text { Squares }\end{array}$} & df & Mean Square & F & $\begin{array}{l}\text { Si } \\
\text { g. }\end{array}$ \\
\hline $\begin{array}{l}\text { Between } \\
\text { Groups }\end{array}$ & 11434,668 & 4 & 2858,667 & 6,445 &, 0 \\
\hline $\begin{array}{l}\text { Within } \\
\text { Groups }\end{array}$ & 30605,890 & 69 & 443,564 & & \\
\hline Total & 42040,558 & 73 & & & \\
\hline
\end{tabular}

Based on the table above, note that the value of sig. 0.000 $<0.05$ thus Ho is rejected. So, there are differences in average Skill Related Physical Fitness among groups that practice sports activities lawn tennis, walking, table tennis, gymnastic, and badminton. rank)

Result of Health-Related Physical Fitness Test (Component

- General endurance: badminton, lawn tennis, table tennis, gymnastics, walking.

- Muscular endurance: lawn tennis, walking, gymnastics, table tennis, badminton.

- Strength: lawn tennis, walking, badminton, gymnastics, table tennis.

- Flexibility: gymnastics, tennis, badminton, table tennis, walking.

- Body mass index: walking, gymnastics, badminton, table tennis, lawn tennis (recap in table 6)

TABLE V. Rank of Health Related Physical Fitness COMPonent

\begin{tabular}{|c|c|c|c|c|c|}
\hline $\begin{array}{ll}\text { Component } & \text { Rank } \\
\end{array}$ & 1 & 2 & 3 & 4 & 5 \\
\hline General endurance & $\begin{array}{l}\text { Badminton } \\
26,7 \%=\text { Low }\end{array}$ & $\begin{array}{l}\text { Lawn tennis } \\
25 \%=\text { Low }\end{array}$ & $\begin{array}{l}\text { Table tennis } \\
18,75 \%=\text { Low }\end{array}$ & $\begin{array}{l}\text { Gymnastic }=100 \% \\
\text { VeryLow }\end{array}$ & $\begin{array}{l}\text { Walking }=100 \% \\
\text { VeryLow }\end{array}$ \\
\hline $\begin{array}{c}\text { Muscle } \\
\text { Endurance }\end{array}$ & $\begin{array}{l}\text { Lawn tennis } \\
58,3 \% \text { Excellence }\end{array}$ & $\begin{array}{l}\text { Walking } \\
37,5 \% \text { Excellence }\end{array}$ & $\begin{array}{l}\text { Gymnastic } \\
33,33 \% \text { Excellence }\end{array}$ & $\begin{array}{l}\text { Table tennis } 18,75 \% \\
\text { Excellence }\end{array}$ & $\begin{array}{l}\text { Badminton } \\
\text { - 0\% Excellence }\end{array}$ \\
\hline Strength & $\begin{array}{l}\text { Lawn tennis } \\
\text { 16,66\%Middle }\end{array}$ & $\begin{array}{l}\text { Walking- } \\
6,25 \% \text { Middle }\end{array}$ & $\begin{array}{l}\text { Badminton } \\
-0 \% \text { Middle } \\
\end{array}$ & $\begin{array}{l}\text { Gymnastic } \\
-0 \% \text { Middle } \\
\end{array}$ & $\begin{array}{l}\text { Table tennis } \\
-0 \% \text { Middle }\end{array}$ \\
\hline Flexibility & $\begin{array}{l}\text { Gymnastic } \\
13,33 \% \text { Good }\end{array}$ & $\begin{array}{l}\text { Lawn tennis } \\
8,33 \% \text { Good }\end{array}$ & $\begin{array}{l}\text { Badminton } \\
100 \% \text { Middle }\end{array}$ & $\begin{array}{l}\text { Table tennis } \\
93,75 \% \text { Middle }\end{array}$ & $\begin{array}{l}\text { Walking } \\
93,75 \% \text { Middle }\end{array}$ \\
\hline $\begin{array}{l}\text { Body } \\
\text { Mass } \\
\text { Index }\end{array}$ & $\begin{array}{l}\text { Walking } \\
62,5 \% \text { Normal }\end{array}$ & $\begin{array}{l}\text { Gymnastic } \\
46,66 \% \text { Normal }\end{array}$ & $\begin{array}{l}\text { Badminton } \\
40 \% \text { Normal }\end{array}$ & $\begin{array}{l}\text { Table tennis } \\
31,25 \% \text { Normal }\end{array}$ & $\begin{array}{l}\text { Lawn tennis } \\
25 \% \text { Normal }\end{array}$ \\
\hline
\end{tabular}

\section{DISCUSSION}

Overall the results of health-related physical fitness test, is expected to be useful as a feedback for further designing programs, maintaining good status, to improve the poor status, according to the ability of elderly individuals, respectively. This is consistent with the proposed by Suni, "The ultimate purpose is to give feedback to the individual in terms of the adequacy of his or her fitness with regard to health criteria. Although our results provide some elements for the development of such criteria" [11]. On the other hand, Arazi states in his research conclusion that "The ability to maintain repetitions and to perform a higher volume of training has been shown to be essential for stimulating greater strength and hypertrophy adaptations" [12].

The higher physical fitness status the higher success feeling in successful aging. The improvement of successful aging on the elderly, describe by Andrzej Knapik, that "This term applies to the minimization of disease and infirmity, to the 
[5] Demura, Y., Tsuchida, T., Ishizaki, T., Mizuno, S., Totani, Y., Ameshima, S., Miyamori, I., Sasaki, M. and Yonekura, Y., 2003. 18FFDG accumulation with PET for differentiation between benign and malignant lesions in the thorax. Journal of Nuclear Medicine, 44(4), pp.540-548.

The better the elderly physical fitness, will increase successful aging feeling for elderly. In this case Andrzej Knapik, describe: "This term (successful aging feeling) applies to the minimization of disease and infirmity, to the maintenance of optimal physical and mental fitness as well as the maintenance of the general life activity" [13].

\section{CONCLUSIONS}

There are differences in the effect of five sport activities id est lawn tennis, walking, table tennis, gymnastics, badminton against health-related physical fitness for elderly.

There are differences in the effect of five sport activities id est lawn tennis, walking, table tennis, gymnastics, badminton against the rank of the dominant components of health-related physical fitness for elderly.

\section{REFERENCES}

[1] U.U.R.I., Nomor 3. Tahun 2005 Tentang Sistem Keolahragaan Nasional. Jakarta: Biro Humas dan Hukum Kementerian Negara Pemuda dan Olahraga Republik Indonesia.

[2] A. Iskandar "Panduan Teknis Tes dan Latihan Kesegaran Jasmani," Jakarta: Pusat Pengkajian dan Pengembangan IPTEK Olahraga Kantor Menpora, 1999.

[3] Kusmaedi, N., 2019, September. Effect of Sport Activity on Elderly Hypokinetic Trend and Risk. In 3rd International Conference on Sport Science, Health, and Physical Education (ICSSHPE 2018). Atlantis Press.

[4] Rikli, R.E. and Jones, C.J., 2013. Senior fitness test manual. Human Kinetics.

[6] Rikli, R.E. and Jones, C.J., 1999. Functional fitness normative scores for community-residing older adults, ages 60-94. Journal of aging and physical activity, 7, pp.162-181.

[7] Fone, S., Lundgren-Lindquist, B., Skogar, Ö. and Levander, B., 2003. Health status and functional capacity in a group of successfully ageing 65-85 year olds. Disability and Rehabilitation, 25(18), pp.1044-1051.

[8] M. Król-Zielińska, K. Kusy, J. Zieliński, and W. Osiński, "Physical activity and functional fitness in institutionalized vs. independently living elderly: A comparison of 70-80-year-old city-dwellers," Archives of gerontology and geriatrics, vol. 53(1), pp.e10-e16, 2011.

[9] J. Lexell, "Ageing and human muscle: observations from Sweden," Canadian Journal of Applied Physiology, vol.18(1), pp. 2-18, 1993.

[10] D.P. Mood, A.W. Jackson, and J.R. Morrow Jr, "Measurement of physical fitness and physical activity: Fifty years of change," Measurement in Physical Education and Exercise Science, vol. 11(4), pp. 217-227, 2007.

[11] J.H. Suni, P. Oja, S.I.Miilunpalo, M.E. Pasanen, I.M.Vuori, and K. Bös, "Health-related fitness test battery for adults: associations with perceived health, mobility, and back function and symptoms," Archives of physical medicine and rehabilitation, vol.79(5), pp. 559-569, 1998.

[12] H. Arazi, and A.Asadi, "Multiple Sets resistance training: Effects of condensed versus circuit models on muscular strength, endurance and body composition," Journal of Human Sport and Exercise, vol. 7(4), pp. 733-740, 2012.

[13] A. Knapik, E. Saulicz, A. Mysliwiec, M. Saulicz, and A. WarmuzWancisiewicz, "Motivations and effects of practicing Nordic Walking by elderly people," Baltic Journal of Health and Physical Activity, vol. 6(1), p.34, 2014. 